\title{
Prevalence of Cervical Human Pappillomavirus Infection in Awka, Nigeria
}

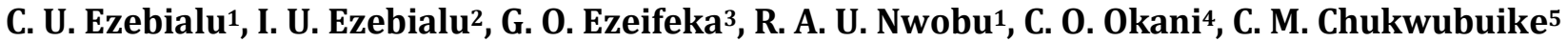 \\ ${ }^{1}$ Department of Applied Microbiology and Brewing, Nnamdi Azikiwe University, Awka, Nigeria \\ ${ }^{2}$ Department of Obstetrics and Gynaecology, College of Medicine Chukwuemeka Odumegwu Ojukwu University, Awka, Nigeria \\ ${ }^{3}$ Department of Veterinary Microbiology and Parasitology, Michael Okpara University of Agriculture, Umudike, Nigeria \\ ${ }^{4}$ Department of Histopathology, College of Medicine Chukwuemeka Odumegwu Ojukwu University, Awka, Nigeria \\ ${ }^{5}$ Virology Unit, Department of Microbiology, University of Nigeria Teaching Hospital, Enugu, Nigeria \\ Email: nenyeume@yahoo.com
}

How to cite this paper: Ezebialu, C.U., Ezebialu, I.U., Ezeifeka, G.O., Nwobu, R.A.U., Okani, C.O. and Chukwubuike, C.M. (2020) Prevalence of Cervical Human Pappillomavirus Infection in Awka, Nigeria. Journal of Biosciences and Medicines, 8, 37-47. https://doi.org/10.4236/jbm.2020.83005

Received: August 29, 2019

Accepted: March 2, 2020

Published: March 5, 2020

Copyright $\odot 2020$ by author(s) and Scientific Research Publishing Inc. This work is licensed under the Creative Commons Attribution International License (CC BY 4.0).

http://creativecommons.org/licenses/by/4.0/

\begin{abstract}
Prevalence of cervical Human Papillomavirus infection and type distribution vary with different environments. Knowledge of this will help in some cervical cancer interventions such as vaccine administration. This study aimed at determining the prevalence of cervical HPV infection among women attending a tertiary hospital in Awka, Nigeria. To evaluate cervical HPV Infections, cervical samples were collected over a period of 1 year from 405 consenting women. Multiplex PCR and cytology were used in the study. Semi-structured questionnaire was used to obtain the demographic characteristics of the participants. Statistical analysis was done using IBM SPSS statistics version 21. The findings showed that of the 405 women, 387 (94.4\%) had normal cytology, and 18 (4.4\%) had Low-grade Squamous Intraepithelial Lesion (LSIL). There was no High-grade Squamous Intraepithelial Lesion (HSIL). HPV prevalence of (79) $19.5 \%$ was obtained overall in the 405 women, (75 of 387) $19.4 \%$ with normal cytology, (4 of 18) $22.2 \%$ with LSIL. Age specific prevalence peaked at age group $30-39$ and a second peak at $60-69$. HPV types obtained were HPV 1631 (7.7\%), HPV 1824 (5.9\%), HPV 353 (0.7\%), HPV 339 (2.2\%), HPV 683 (0.7\%) and multiple infections (9) 2.2\%. HPV 16 was the only type found in LSIL. Regular HPV typing and screening of our women for HPV infection and Pap's smear can go a long way in the reduction of cervical cancer.
\end{abstract}

\section{Keywords}

Prevalence, HPV Infection, Cervical Cancer, Cytology, Intraepithelial Lesion 


\section{Introduction}

HPV is a sexually transmitted infection and all sexually active women are at the risk of HPV acquisition. Up to $50 \%$ of sexually active women will be infected with HPV in their lifetime [1] and it is estimated that, by the age of 50, at least 80 percent of women will have acquired sexually transmitted HPV [1]. Most women are infected shortly after their first sexual intercourse [2]. Although all age groups can be affected, there appears to be a higher prevalence in the young women [3] [4] [5] [6].

HPV 16 has been found to be the most prevalent in most parts of the world [5] [7], though with variations in some places. In Kenya [8], Burkina-Faso [9] and Zimbabwe [10], HPV 52 was more prevalent; in Irun Nigeria [11], and Abuja Nigeria [12], HPV 35 was most prevalent; while in Senegal [13] and Nigeria [14], HPV 16/58 and HPV 16/35 respectively were more prevalent. Hibbits et al. (2006) [15] reported high prevalence of HPV 16 and 35.

The prevalence of HPV ranged from $1.5 \%$ in Spain [16] to $38.8 \%$ in Kenya [8]. In Nigeria, different figures have been documented in the different zones of the country. In Ibadan, South-West Nigeria, cervical HPV was identified in $26.3 \%$ of sexually active women above 15 years [14] and $14.7 \%$ among 1282 women in Irun [12]. In Okene, North-Central Nigeria, a prevalence of 21.6\% among 231 women were documented [17]. In Abuja, the Federal Capital, the prevalence was $37 \%$ among 275 women studied [12].

The available HPV vaccines so far can only take care of 9 HPV types. Regional variation in HPV serotypes may influence the effectiveness of the vaccines in the different regions. There is paucity of data on the prevalence of HPV and serotypes in this region. The present study is designed to study the prevalence of and factors associated with cervical HPV infection.

\section{Method}

The study was carried out at Chukwuemeka Odumegwu Ojukwu University Teaching Hospital (COOUTH), Awka in Awka South Local Government Area, Anambra State. Chukwuemeka Odumegwu Ojukwu University Teaching Hospital (COOUTH) is a tertiary hospital serving as a referral centre for Hospitals in Awka North and South Local Government Areas and beyond. The study population was women attending the different clinics at Chukwuemeka Odumegwu Ojukwu University Teaching Hospital Awka. Prospective participants were approached and given information concerning the study and consenting women were recruited for the study. Since human subjects were used, ethical approval was obtained from the hospital ethics committee.

Four hundred and five consenting women were recruited into the study. The sample size was derived using the formula:

$$
N=Z^{2} p q / d^{2}[18],
$$

where $Z=$ standard deviation at 1.96 (which corresponds to $95 \%$ confidence interval). 


$$
\begin{aligned}
& P=\mathrm{HPV} \text { prevalence at Ibadan }=26.3 \%[14] . \\
& \begin{array}{l}
q=1-P . \\
d=\text { degree of accuracy/precision expected }=0.05
\end{array} \\
& \text { Substituting for the above formula: }
\end{aligned}
$$

$$
N=1.96 \times 1.96 \times 0.263 \times 0.737 /(0.05)^{2}=286.577,
$$

Addition of $20 \%$ attrition, sample size $=345$.

Women who had undergone hysterectomy, are physically and mentally unable to undergo an interview and pelvic examination, were pregnant and were menstruating at the time of this study were excluded. Socio-demographic details of the subjects were obtained using previously pretested semi-structured and researcher administered questionnaire. The smoking habits, reproductive history, sexual habit of the women and their partners, previous exposure to STDs, and life time use of contraceptives were also obtained.

For the collection of cervical smears, each woman was placed in the dorsal position in a consulting clinic where privacy was assured and in the presence of a chaperone. The cervix was exposed using sterile disposable speculum. An Ayre spatula was then passed into the cervix and rotated through 360 degrees. This was immediately smeared on a glass slide and fixed immediately in $95 \%$ alcohol before transferring it to the cytology laboratory. A cytobrush was subsequently inserted into the cervical canal and rotated through 360 degrees. The cytobrush was removed, broken and transferred into a collection bottle containing Phosphate Buffered Saline (PBS) and stored at $-20^{\circ} \mathrm{C}$ until it was transferred to the laboratory for HPV DNA test.

\subsection{HPV DNA Isolation and Typing}

The cervical samples were pre-treated and Viral DNA was extracted from GITC lysates using High Pure Viral DNA kit (Roche, UK) following the manufacturer's instructions. The High Pure Kit uses Spin Column method of DNA extraction. This was carried out according to manufacturer's instruction.

Typing of HPV DNA was done using Multiplex PCR. Four sets of multiplex PCR was carried out using Eppendorf Mastercycler Nexus Gradient (Eppendorf, Germany). The primers were designed based on E1, E6 - E7 and L1 regions of the HPV genome.

The Primer sets were: GP168 (for HPV types 11, 16, 18 and any other type); MY313 (for HPV types 31, 33 and others), OLIS35 (for HPV35 and others), and CpG mix were used for the HPV detection. All primers were synthesized by Invitrogen UK (Life Technology, UK). For all reactions, the Platinum Multiplex PCR Master Mix (Life Technology, UK) was used.

Viral DNA samples were thawed. A worksheet was created. Reactions were set up in 96 well PCR plate (thin walled) and sealed after all additions and placed in a PCR machine (Eppendorf master cycler). The thermal profile was set up and PCR was allowed to run. The plate was brought out and electrophoresis was performed on all the specimens. The gel was carefully brought out and viewed 
under the UV light.

The images were captured using Genome-mini Gel documentation system (VWR, UK) and transferred to computer where they were stored for interpretation of the results. Amplicons were read using the known sizes and DNA ladder.

\subsection{Cervical Cytology (Papanicolau Test)}

In the cytology laboratory, the slide fixed smears were stained and examined microscopically for the dyplastic cells as characterized by anaplasia, hyperchromatism and large nucleus. The staining was done following the Papanicolau conventional method and a cytopathologist read all the slides and reported them following the Bethesda classification.

\section{Results}

\subsection{Demographic Characteristics of the Participants}

The mean age of the 405 participants was $39.97 \pm 9.25$ years. They were predorminantly of the Igbo ethnic group 388 (95.6\%) and Christians 407 (99.3\%). The socio-demographic characteristics of the respondents are shown in Table 1.

\subsection{Prevalence of HPV Infection}

Out of the 405 subjects, HPV DNA was detected in 79 giving a prevalence of $19.5 \%$. The commonest HPV serotype identified was HPV 16 which was seen in 7.7\% (31/405) followed by HPV 18 accounting for 5.9\% (24/405). HPV 33 occurred in $2.2 \%$, HPV 35 occurred in $0.7 \%$ while HPV 68 occurred in $0.7 \%$. Infection with multiple serotypes of HPV was present in $2.2 \%$ of the women. The prevalence was highest among those aged 30 - 35 years while the lowest prevalence was among ages 50 - 59. Figure 1 shows the graphic representation of the age specific prevalence of HPV in these women showing a double peak at ages 30

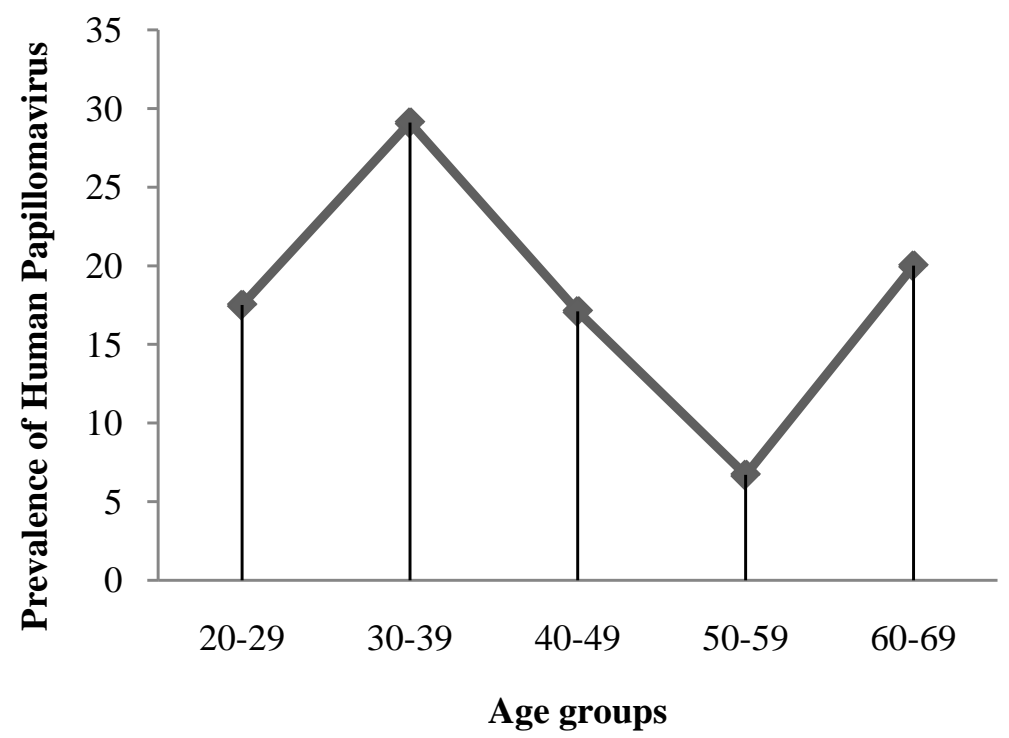

Figure 1. The age specific prevalence of HPV infection among the participants. 
Table 1. Socio-demographic characteristics of the respondents.

\begin{tabular}{|c|c|c|}
\hline Variable & Frequency & Percentage \\
\hline \multicolumn{3}{|l|}{ Age $(N=405)$} \\
\hline $20-29$ & 57 & 14.1 \\
\hline $30-39$ & 125 & 31.4 \\
\hline $40-49$ & 152 & 37.5 \\
\hline $50-59$ & 59 & 14.6 \\
\hline $60-69$ & 10 & 2.5 \\
\hline \multicolumn{3}{|l|}{ Marital Status $(\mathrm{N}=405)$} \\
\hline Married & 273 & 67.4 \\
\hline Single & 81 & 20.0 \\
\hline widowed & 51 & 12.6 \\
\hline \multicolumn{3}{|c|}{ Level of Education $(\mathrm{N}=405)$} \\
\hline No formal education & 17 & 4.2 \\
\hline Primary level & 40 & 9.9 \\
\hline Secondary level & 123 & 30.4 \\
\hline Tertiary level & 225 & 54.9 \\
\hline \multicolumn{3}{|l|}{ Ethnicity $(\mathrm{N}=405)$} \\
\hline Igbo & 388 & 95.6 \\
\hline Hausa & 4 & 1.0 \\
\hline Yoruba & 4 & 1.0 \\
\hline Others & 9 & 2.2 \\
\hline \multicolumn{3}{|l|}{ Religion $(\mathrm{N}=405)$} \\
\hline Christianity & 402 & 99.3 \\
\hline Islam & 3 & 0.7 \\
\hline \multicolumn{3}{|c|}{ Age at coiterchy $(N=405)$} \\
\hline$\leq 17$ years & 76 & 18.8 \\
\hline$>17$ years & 329 & 81.2 \\
\hline \multicolumn{3}{|l|}{ HIV status $(\mathrm{N}=364)$} \\
\hline Positive & 126 & 34.6 \\
\hline Negative & 238 & 65.4 \\
\hline Not sure & 45 & 8.9 \\
\hline \multicolumn{3}{|l|}{ History of STI (362) } \\
\hline Yes & 177 & 48.9 \\
\hline No & 185 & 51.1 \\
\hline
\end{tabular}

- 39 and 60 - 69. Eighteen women out of the 405 had abnormal cervical cytology in the form of Low-Grade Squamous Intraepithelial Lesion giving a prevalence of $4.4 \%$. The prevalence of HPV infection in these women with abnormal cervical cytology was $22.2 \%$ while it was $19.4 \%$ among those with normal cervical cytology. Only HPV 16 was isolated from women with abnormal cytology.

With bivariate analysis, significant factors associated with HPV infection were age less than $40(P=0.008)$, being married $(P=0.001)$, early coitarchy $(P<$ $0.001)$, multiple sexual partners $(P=0.02)$, history of previous STI $(P<0.01)$, and cigarette smoking $(P=0.001)$ (Table 2$)$. However, when subjected to multiple logistic regression, only young age $(P=0.01, \mathrm{OR}=0.42[0.21,0.84])$, early coitarchy $(P \leq 0.001, \mathrm{OR}=0.21[0.1,0.43])$ and multiple sexual partners $(P=$ $0.01, \mathrm{OR}=0.4[0.19,0.82])$ remained significant. 
Table 2. Association between HPV infection and select variables.

\begin{tabular}{|c|c|c|c|c|}
\hline \multirow[t]{2}{*}{ Variable } & \multicolumn{2}{|c|}{ HPV positive } & \multirow[t]{2}{*}{ Chi Square } & \multirow[t]{2}{*}{$P$-value } \\
\hline & No & $\%$ & & \\
\hline \multicolumn{5}{|l|}{ Age } \\
\hline$<40(184)$ & 46 & 25.0 & 6.5 & 0.010 \\
\hline$\geq 40(221)$ & 33 & 14.9 & & \\
\hline \multicolumn{5}{|l|}{ Marital status } \\
\hline Single (132) & 13 & 9.8 & \multirow{2}{*}{11.6} & \multirow{2}{*}{0.0006} \\
\hline Married (273) & 66 & 24.2 & & \\
\hline \multicolumn{5}{|l|}{ Age at coitarchy } \\
\hline$\leq 17(76)$ & 30 & 39.5 & \multirow{2}{*}{23.8} & \multirow{2}{*}{$<0.001$} \\
\hline$>17(329)$ & 49 & 14.9 & & \\
\hline \multicolumn{5}{|l|}{ Type of marriage } \\
\hline Monogamy & 64 & 21.7 & \multirow{2}{*}{0.53} & \multirow{2}{*}{0.47} \\
\hline Polygamy & 8 & 27.6 & & \\
\hline \multicolumn{5}{|c|}{ Multiple sex partners } \\
\hline Yes (193) & 46 & 23.8 & \multirow{2}{*}{5.2} & \multirow{2}{*}{0.02} \\
\hline No (203) & 30 & 14.8 & & \\
\hline \multicolumn{5}{|l|}{ History of STI } \\
\hline Yes (177) & 52 & 29.4 & \multirow{2}{*}{18.3} & \multirow{2}{*}{$<0.001$} \\
\hline No (185) & 21 & 11.4 & & \\
\hline \multicolumn{5}{|l|}{ On Contraceptive } \\
\hline Yes (162) & 40 & 24.7 & \multirow{2}{*}{3.2} & \multirow{2}{*}{0.07} \\
\hline No $(210)$ & 36 & 17.1 & & \\
\hline \multicolumn{5}{|l|}{ Cigarette smoking } \\
\hline Yes & 3 & 100 & \multirow{2}{*}{12.4} & \multirow{2}{*}{0.0004} \\
\hline No & 76 & 19.1 & & \\
\hline \multicolumn{5}{|l|}{ HIV status } \\
\hline Yes (126) & 19 & 15.1 & \multirow{2}{*}{2.7} & \multirow{2}{*}{0.10} \\
\hline No & 54 & 22.2 & & \\
\hline Anti-retroviral dr & & & & \\
\hline Yes (102) & 12 & 11.8 & 46 & 003 \\
\hline No $(24)$ & 7 & 29.2 & 4.6 & 0.03 \\
\hline Cervical smear & & & & \\
\hline Normal (387) & 75 & 19.4 & 0.09 & 0.77 \\
\hline Abnormal (18) & 4 & 22.2 & & \\
\hline
\end{tabular}

\section{Discussion}

The prevalence of HPV infection obtained in this work (19.4\%) among cytologically normal women and $19.5 \%$ in the overall women is comparable to other results obtained from different parts of the country. Prevalence of $14.7 \%$ was obtained from Irun Nigeria [11], 21.6\% in Okene, Nigeria [17], 26.3\% among cytologically normal women in Ibadan Nigeria [14], 19.6\% in western Nigeria [19] and the highest prevalence was obtained 37\% in Abuja Nigeria [12]. Higher prevalence has been recorded in other African countries-38.8\% in Kenya [8], 74\% among young girls in Tanzania [6] and even lower prevalence (12.5\%) in Senegal [13]. 
The differences may be influenced by the age group studied, environment and variations in assays methods.

Age specific prevalence recorded in this research was highest in age group 30 $39(29.1 \%)$ and a slight peak in the age group 60 - 69 (20.0\%). The two peaks in the middle and old ages were also observed by Thomas et al. [14] in Ibadan, Nigeria. In Irun Nigeria, HPV prevalence did not decline with age but with slight peaks in women $15-29$ and 60 - 69 years old [11] while in Abuja (Nigeria), there was a steady decline of HPV prevalence in older women [12]. In other parts of the world, very high prevalence in the younger age [3] [4] [5] and a steady decline in the older age [8] [20] [21] have been recorded.

Age group as a factor in HPV acquisition has remained almost the same in all parts of our country-Nigeria with slight differences. High prevalence of HPV infection in a very young age [11] [12], middle age group [14] and a second peak in the old age has been consistent. This work equally witnessed the same pattern, though none of the participants were less than 20 years (the age at which the highest prevalence occurs). The high prevalence in the middle group may have been because this is a hospital-based research, thereby attracted more women of child bearing age that tend to go to hospital more often. The second peak in the old age may probably be because of acquisition of new sexual partners later in life especially among the widows [14].

In this study, HPV 16 was the most prevalent serotype and this is consistent with findings from other studies [5] [7] [21]. However, the finding differs from others within Nigeria and Africa where serotypes 35 and 52 were more prevalent [8] [9] [11] [12]. This difference in type specific prevalence from place to place according could be influenced by the type of assay used and by the high proportion of multiple HPV infection in certain populations. Okolo et al. [22]., argued that even though HPV 35 may have been reported in Nigeria, the risk of developing invasive cervical cancer was more in the individuals infected with HPV 16 and 18 than those with other high-risk types.

HPV is a sexually transmitted infection and this study has demonstrated a relationship between sexual behaviour and HPV infection. Early commencement of sexual activity, history of STI and having multiple sexual partners were significantly related to HPV infection.

Early age at first sexual intercourse may be considered an indicator for early age at first exposure to HPV and other STIs [23] [24]. In this study, HPV infection was found to be higher among the participants that had their first sexual intercourse before the age of 17 and this is consistent with findings from other studies [25] [26] [27].

Contrary to what would be expected, HIV positivity did not significantly affect the prevalence of HPV infection. This may however be because the proportion of the respondents is small and so not powered enough to detect such difference. Again, the use of anti-retroviral drugs may also be modifying the influence of HIV infection on host response to other infective organisms. This may actually explain the finding of a significantly higher prevalence among HIV pos- 
itive respondents receiving anti-retroviral drugs in this study. Ezechi et al. [19] equally reported higher prevalence of HPV infection among HIV patients that were not on ARD in South Western Nigeria.

\section{Conclusion}

Prevalence of HPV infection in this study is $19.4 \%$ among women with normal cytology, and $22.2 \%$ among women with low grade squamous intraepithelial lesion (LSIL). Five different HPV types (16, 18, 33, 35 and 68) were identified using multiplex PCR. Multiple HPV types (2.2\%) were equally detected in some samples. The most prevalent HPV type was HPV 16 (7.7\%). HPV prevalence was bimodal with the first peak in the age group 30 - 39 and second peak at age group 60 - 69. Some factors including early age at first sexual intercourse, marriage, polygamous marriage, multiple sexual partners, smoking, and age were found to be positively associated with HPV transmission. This study has also shown that the currently available HPV vaccines will cover for the predominant HPV types in this study population.

\section{Limitations and Strengths}

The strength of this work was our ability to type the HPV DNA, thereby making it possible to identify the prevalent HPV type in Awka. The limitation was that it was a hospital-based research, hence may not represent the true population. The young girls that usually have the highest prevalence of HPV infection [3] [4] [5] were not captured in this work and that may have affected the age prevalence peaks.

\section{Conflicts of Interest}

The authors declare no conflicts of interest regarding the publication of this paper.

\section{References}

[1] Centre for Disease Control and Prevention (2007) Human Papillomavirus: HPV Information for Clinicians. https://www.cdc.gov/std/hpv

[2] Plummer, M., Peto, J., Franceschi, S., Rajkumar, T., Cuzick, J., Appleby, P. and International Collaboration of Epidemiological Studies of Cervical Cancer (2012) Time Since First Sexual Intercourse and the Risk of Cervical Cancer. International Journal of Cancer, 130, 2638-2644. https://doi.org/10.1002/ijc.26250

[3] Hildeshieim, A., Schiffman, M.H., Gravitt, P.E., Glass, A.G., Greer, C.E., Zhang, T., Scott, D.R., Rush, B.B., Lawler, P. and Sherman, M.E. (1994) Persistence of Type Specific Human Papillomavirus Infection among Cytologically Normal Women. The Journal of Infectious Diseases, 169, 235-240. https://doi.org/10.1093/infdis/169.2.235

[4] Schiffman, M. and Castle, P.E. (2003) Human Papillomavirus: Epidemiology and Public Health. Archives-Pathology and Laboratory Medicine, 127, 930-934.

[5] Mejlede, N., Bonde, J. and Formsgaard, A. (2009) High Frequency of Multiple HPV 
Types in Cervical Specimens from Danish Women. Acta Pathologica, Microbiologica et Immunologica Scandinavica, 117, 108-114. https://doi.org/10.1111/j.1600-0463.2008.00019.x

[6] Watson-Jones, D., Baisley, K., Brown, J., Kavishe, B., Andreasen, A., Changalucha, J., Mayaud, P., Kapiga, S., Gumodoka, B., Hayes, R.J. and de Sanjosé, S. (2013) High Prevalence and Incidence of Human Papillomavirus in a Cohort of Healthy Young African Female Subjects. Sexually Transmitted Infections, 89, 358-365. https://doi.org/10.1136/sextrans-2012-050685

[7] Goncalves, A.M.G., Randi, G., Arslan, A., Villa, L.L., Burattini, M.N., Franceschi, S., Donadi, E.A. and Massad, E. (2008) HPV Type Infection in Different Anogenital Sites among HIV-Positive Brazillian Women. Infectious Agents and Cancer, 3, Article No. 5. https://doi.org/10.1186/1750-9378-3-5

[8] De Vuyst, H., Steyaert, S., van Retergherm, L., Claeys, P., Muchiril, L., Sitati, S., Vansteelandt, S., Quint, W., Kleeter, B., Van Marck, E. and Temmerman, M. (2003) Distribution of Human Papillomavirus in a Family Planning Population in Nairobi Kenya. Sexually Transmitted Diseases, 30, 137-142. https://doi.org/10.1097/00007435-200302000-00009

[9] Didelot-Rousseau, M.N., Nagot, N., Costes-Martineau, V., Valles, X., Ouedraogo, A., Konate, I., Weiss, H.A., Van de Perre, P., Mayaud, P., Segondy, M. and Yerelon Study Group (2006) Human Papillomavirus Genotype Distribution and Cervical Squamous Intraepithelial Lesions among High-Risk Women with and without HIV-1 Infection in Burkina Faso. British Journal of Cancer, 95, 355-362. https://doi.org/10.1038/sj.bjc.6603252

[10] Gravitt, P.E., Kamath, A.M., Gaffikin, L., Chirenje, Z.M., Womack, S. and Shah, K.V. (2002) Human Papillomavirus Genotype Prevalence in High Grade Squamous Intra-Epithelial Lesions and Colposcopically Normal Women from Zimbabwe. International Journal of Cancer, 100, 729-732. https://doi.org/10.1002/ijc.10538

[11] Gage, J.C., Ajenifuja, K.O., Wentzensen, N.A., Adepiti, A.C., Eklund, C., Reilly, M., Hutchinson, M., Wacholder, S., Harford, J., Soliman, A.S., Burk, R.D. and Schiffman, M. (2012) The Age-Specific Prevalence of Human Papillomavirus and Risk of Cytologic Abnormalities in Rural Nigeria: Implications for Screen-and-treat Strategies. International Journal of Cancer, 130, 2111-2117. https://doi.org/10.1002/ijc.26211

[12] Akarolo-Anthony, S.N., Famooto, A.O., Dareng, B.O., Olaniyan, O.B., Offiong, R., Wheeler, C.M. and Adebamowo, C.A. (2014) Age-Specific Prevalence of Human Papillomavirus Infection among Nigerian Women. BMC Public Health, 14, 656-662. https://doi.org/10.1186/1471-2458-14-656

[13] Xi, L.F., Toure, P., Critchlow, C.W., Hawes, S.E., Dembele, B., Sow, P.S. and Kiviat, N.B. (2003) Prevalence of Specific Types of Human Papillomavirus and Cervical Squamous Intra-Epithelial Regions in Consecutive, Previously Unscreened WestAfrican Women over 35 Years of Age. International Journal of Cancer, 103, 788-793. https://doi.org/10.1002/ijc.10876

[14] Thomas, J.O., Herrero, R., Omigbodun, A.A., Ojemakinde, K., Ajayi, I.O., Fawole, A., Oladepo, O., Smith, S., Arslan, A., Munoz, N., Snijders, P.J.F., Meijer, C.J.L.M. and Franceschi, S. (2004) Prevalence of Papillomavirus Infection in Women in Ibadan, Nigeria: A Population Based Study. British Journal of Cancer, 90, 638-645. https://doi.org/10.1038/sj.bjc.6601515

[15] Hibbits, S., Rieck, G.C., Hart, K., Powell, N.G., Beukenholdt, R., Dallimore, N., McRea, J., Hauke, A, Tristram, A. and Fiander, A.N. (2006) Human Papillomavirus Infection: An Anonymous Prevalence Study in South Wales, UK. British Journal of 
Cancer, 95, 226-232. https://doi.org/10.1038/sj.bjc.6603245

[16] de Sanjose, S., Diaz, M., Castellsague, X., Clifford, G., Bruni, L., Munoz, N. and Bosch, X.F. (2007) Worldwide Prevalence and Genotype Distribution of Cervical Human Papillomavirus DNA in Women with Normal Cytology: A Meta-Analysis. The Lancet Infect Diseases, 7, 453-459. https://doi.org/10.1016/S1473-3099(07)70158-5

[17] Schnatz, P.F., Markelova, N.V., Holmes, D., Mandavilli, S.R. and O'Sullivan, D.M. (2008) The Prevalence of Cervical HPV and Cytological Abnormalities in Association with Reproductive Factors of Rural Nigerian Women. Journal of Women's Health, 17, 279-285. https://doi.org/10.1089/jwh.2006.0295

[18] Araoye, M.O. (2003) Subject Selection. In: Research Methodology with Statistics for Health and Social Sciences, Nathadex Publishers, Ilorin, Nigeria, 115-121.

[19] Ezechi, O.C., Ostergren, P.O., Nwaokorie, F.O., Ujah, I.A.O. and Pettersson, K.O. (2014) The Burden, Distribution and Risk Factors for Cervical Oncogenic Human Papillomavirus Infection in HIV Positive Nigerian Women. Virology Journal, 11, 5. https://doi.org/10.1186/1743-422X-11-5

[20] Serwadda, D., Wawer, M.J., Shah, K.V., Sewankambo, N.K., Daniel, R., Li, L.A., Meehan, M.P., Wabwire-Mangen, F. and Gray, R.H. (1999) Use of a Hybrid Capture Assay of Self Collected Vaginal Swabs in Rural Uganda for Detection of Human Papillomavirus. Journal of Infectious Diseases, 180, 1316-1319. https://doi.org/10.1086/315026

[21] Castellsague, X., Memedez, C., Loscertales, M.P., Kornegay, J.R., dos Santos. F., Gomez-Olive, F.X., Llolveras, B., Abarca, N., Vaz, N., Barreto, A., Bosch, F.X. and Alonso, P. (2001) Human Papillomavirus Genotypes in Rural Mozambique. The Lancet, 358, 1429-1430. https://doi.org/10.1016/S0140-6736(01)06523-0

[22] Okolo, C., Franceschi, S., Adewole, I., Thomas, J.O., Follen, M., Snijders, P.J.F., Meijer, C.J.L.M. and Clifford, G.M. (2010) Human Papillomavirus Infection in Women with and without Cervical Cancer in Ibadan, Nigeria. Infectious Agents and Cancer, 5, Article No. 24. https://doi.org/10.1186/1750-9378-5-24

[23] Heywood, W., Patrick, K., Smith, A.M.A. and Pitts, M.K. (2015) Associations between Early First Sexual Intercourse and Later Sexual and Reproductive Outcomes: A Systematic Review of Population-Based Data. Archives of Sexual Behaviour, 44, 531-569. https://doi.org/10.1007/s10508-014-0374-3

[24] Lara, L.S.A. and Abdo, C.H.N. (2015) Age at Initial Sexual Intercourse and Health of Adolescent Girls. Journal of Pediatric and Adolescent Gynecology, 29, 1-7. https://doi.org/10.1016/j.jpag.2015.11.012

[25] Ho, G.F.Y., Bierman, R., Beardsley, L. and Burk, R.D. (1998) Natural History of Cervicovaginal Papillomavirus Infection in Young Women. New England Journal of Medicine, 338, 423-428. https://doi.org/10.1056/NEJM199802123380703

[26] Bosch, F.X., Lorincz, A., Munoz, N., Meijer, C.J. and Shah, K.V. (2002) The Causal Relation between Human Papillomavirus and Cervical Cancer. Journal of Clinical Pathology, 55, 244-265. https://doi.org/10.1136/jcp.55.4.244

[27] Kahn, J.A., Rosenthal, S.L., Succop, P.A., Ho, G.F.Y. and Burk, R.D. (2002) Mediators of the Association between Age of First Sexual Intercourse and Subsequent Human Papillomavirus Infection. Paediatrics, 109, e5-e12. https://doi.org/10.1542/peds.109.1.e5 


\section{Appendix I: Questionnaire}

QUESTIONNAIRE 1 (the information given here is confidential. This is to be used in determining the risk factors associated with HPV infection

1) Age. Phone number

2) Place of residence

3) Occupation (a) trader (b) civil servant (c) commercial sex worker (d) others (specify)

4) Marital Status (a) single (b) married (c) widowed (d) divorced

5) Husband's occupation (if married)

6) Level of education (a) no formal education (b) primary (c) secondary (d) tertiary

7) Ethnicity (a) Igbo (b) Hausa (c) Yoruba (d) others

8) Religion (a) traditionalist (b) Muslim (c) Christianity (d) others

9) Denomination (for Christians) (a) Roman Catholic (b) Pentecostal (c) protestants

10) Age at first sexual intercourse

11) Type of marriage (a) monogamous (b) polygamous

12) Does your husband have any extramarital relationship (a) yes (b) no (c) not sure

13) Number of sexual partners (cumulative) (a) one (b) two (c) more than two (d) numerous

14) How many times have you delivered before?

15) Do you smoke (a) yes (b) no (c) smoked before

16) If you have stopped smoking, when was that (a) <a month (b) <a year (c) >a year

17) How often do you smoke (a) very often (b) once in a while

18) HIV status (a) positive (b) negative (c) not sure

19) Are you on ARD (Anti-Retroviral Drugs) (a) yes (b) no

20) What kind of contraceptive do you use (a) condom (b) hormonal contraceptive (c) intra-uterine device

21) Do you have any abnormal vaginal discharge (a) yes (b) no (c) not sure

22) Do you have any vaginal rash (a) yes (b) no (c) not sure

23) Have you been treated of any sexually transmitted infection before (a) yes (b) no (c) not sure 